\title{
$5 S$ in Perfect Deliveries, on Time, Complete and Invoices in Industrial Companies, Lima
}

\author{
Marco Sullo-Rosello ${ }^{\circledR}$, Natividad Carmen Orihuela-Ríos' ${ }^{\circledR}$, Victoria Gardi-Melgarejo² ${ }^{(0)}$, \\ Fernando Alexis Nolazco-Labajos ${ }^{3}\left({ }^{\circ}\right.$, Carlos Oswaldo Venturo-Orbegoso ${ }^{1}$ (), \\ Irma Milagros Carhuancho-Mendoza ${ }^{2 *}$, Rosa Ysabel Moreno-Rodríguez ${ }^{2}$ (D) \\ ${ }^{1}$ University César Vallejo, Escuela de Post Grado, Lima, Perú \\ ${ }^{2}$ University Norbert Wiener, Facultad de Ingeniería y Negocios, Lima, Perú \\ ${ }^{3}$ University San Ignacio de Loyola, Escuela de Post Grado, Lima, Perú \\ Email: ^irmamilagros@yahoo.com
}

How to cite this paper: Sullo-Rosello, M., Orihuela-Ríos, N.C., Gardi-Melgarejo, V., Nolazco-Labajos, F.A., Venturo-Orbegoso, C.O., Carhuancho-Mendoza, I.M. and Moreno-Rodríguez, R.Y. (2020) 5S in Perfect Deliveries, on Time, Complete and Invoices in Industrial Companies, Lima. Open Journal of Business and Management, 8, 960-970.

https://doi.org/10.4236/ojbm.2020.82060

Received: February 28, 2020

Accepted: March 27, 2020

Published: March 30, 2020

Copyright $\odot 2020$ by author(s) and Scientific Research Publishing Inc. This work is licensed under the Creative Commons Attribution International License (CC BY 4.0).

http://creativecommons.org/licenses/by/4.0/ (c) (i) Open Access

\begin{abstract}
The objective of the study was to demonstrate that the application of the $5 \mathrm{~s}$ improved perfect, timely, complete, and trouble-free deliveries in industrial companies, Lima. Because it was observed in five industrial companies located in Callao, Villa El Salvador, San Juan de Lurigancho and Huachipa that they had excessive customer complaints regarding the reception of their orders, they arrived incomplete, missing or did not correspond to the purchase order. This is a fact that unfortunately led to businesses being left short and unable to sell, in addition to the problem with SUNAT because they did not have the invoices in time to make tax payments. That is why it was decided with the permission of the managers and owners of the companies to apply the $5 \mathrm{~s}$ methodology. Although, in the beginning, there was distrust, after the implementation and change of attitude of the employees, it was possible to have more significant support. The intervention was carried out in May, June, and July, where in the first stage it was explained about the new methodology, then the warehouse and the picking area had to be ordered with the workers themselves, where it was possible to discard approximately two tons of waste. Also, the lighting increased, as well as ventilation. Then the staff was instructed daily before the workday, and at the end of the day, everyone supported leaving the space for the next day clean and tidy. Then, in October, November, and December, we proceeded to measure the KPIs in the post-test phase; we must specify that the talks were conducted inter daily. Consequently, the results showed drastic improvements in the four KPIs, and then with the Student T-test, the calculated value of the level of significance was found to be 0.000 , less than 0.05 , which is why the null hypothesis was rejected. It was shown that Indeed, the application of the $5 \mathrm{~s}$ improved perfect,
\end{abstract}


timely, complete deliveries and trouble-free invoices in industrial companies, Lima.

\section{Keywords}

Deliveries, KPI, Invoices, Picking, Industry

\section{Introduction}

Companies every day improve their processes and customer service time, with the aim of not losing the won market, but at the same time attracting new customers through the image of the brand. However, companies have acute problems in the distribution of products, according to the report of McKinsey \& Company in Mexico, it is because of the traffic that exists in the cities, that makes time increase and the product arrives at the destination late [1]. In the United States, companies have problems due to the shortage of warehouses, which is why orders are not dispatched on time, because space is not enough, but also location [2]. In Colombia, the reality is similar to the Mexican one, even more, so its download times reach 20 hours, and the cost of the product becomes more expensive [3].

The Peruvian reality is similar to the previous ones; the stores are located at the periphery of the city of Lima, which makes transport times longer, and logical costs too, even more so that every day the traffic is chaotic, which is the reason why the products are not delivered in time, and customers continuously complain.

Five industrial companies whose factories and distribution centers are located in Callao, Villa el Salvador, San Juan de Lurigancho, and Huachipa participated in the study. The problem in common is the failure to deliver orders and, therefore, customer satisfaction. The factors that affect it are noncompliance in the preparation of the orders. The workplace is messy; the orders are mixed; the wrong location of the tables and shelves, and other elements make the delivery of the products incomplete, or it does not correspond to what is required.

For the study, different investigations were reviewed, such as Al Amin, Roy, Rahman, \& Imran (2019), who also implemented the 5s to organize waste through the use of different colored cans, which is why productivity and efficiency improved [4]. Rizkya, Syahputri, Sari, \& Siregar (2019), through the 5s methodology, managed to reduce the search for resources by $18.75 \%$ in addition to the optimal use of space by $11.20 \%$ [5]. Jiménez, Romero, Fernández, Espinosa, \& Domínguez (2019) achieved the reduction of accidents because the materials and resources were returned to their initial location and did not hinder the traffic [6]. Zubia, Brito, \& Fereiro (2018) and Hernández, Camargo, \& Martínez (2015) achieved cost reduction, improved human relationships, and therefore the employee's satisfaction, demonstrating that the 5 s methodology proves to be 
useful both internally and externally [7] [8].

Loayza (2019) achieved a higher turnover of inventories, the transfer and movement of the collaborator in the plant were reduced by $20 \%$, it took better advantage of the spaces by $50 \%$, the image before the clients improved and the efficiency increased by $40 \%$ [9]. De la Cruz (2018) showed that with the application of the $5 \mathrm{~s}$, the meter offices are improved, and he demonstrated it with the test of the hypothesis with the Student T-test, $\mathrm{p}=0.000$ [10].

The study is based on scientific administration, whose objective is to improve production methods and achieve the goals of the organization [11]. Also critical is the classical theory, whose objective is efficiency and positive relationship between dependent areas [12]. Likewise, the theory of restrictions and systems was considered, because weaknesses or weaknesses in the friction must be overcome, so that the processes flow, the system does not stop, and the planned goals are achieved [13] [14].

Consequently, the measurement of the results will be carried out through the KPIs, which are numerical relationships used in the business field, not only to measure, but also to compare the situation, and of course, it is immediately corrected in the process [14].

The 5s methodology is born in the Toyota company [8], it is considered a philosophy whose raison d'être is to create and organize the work center accurately, in such a way that the efficiency and productivity of organizations is achieved, and therefore the best employee performance, which will also be reflected in the organizational climate and job satisfaction. It is also based on a clean and ergonomic environment. In summary, it is a practical and powerful methodology based on the attitude of the collaborators, which achieves fantastic results for the organization. However, to maintain it requires audits and periodic feedback processes; otherwise, it will fail [15] [16] [17]. The assumptions are based on the selection, systematization, cleaning, standardization, implication and maintenance, self-discipline. The $5 \mathrm{~s}$ are constituted by 1 ) Seiri, order-centered activity; 2) seiton, classification, space for each article or element; 3) seiso, cleanliness, maintain the workplace as found; 4) seiketsu, rules, and maintenance of quality and time standards; 5) shitsuke, monitoring, evaluation and continuous improvement of processes [9] [16] [17].

Consequently, the management of the warehouses has as one of its objectives the delivery of the products in the planned time to achieve customer satisfaction, which is why there must be harmony between the supply and distribution [18]. Some frequent errors are the loss of products, repeated circuits, and lack of use of labor [19]. Customer satisfaction depends on the logistics area, correctly picking. Otherwise, you will have to address the problems of returns and claims for the delivery of missing or those that do not correspond to what is called reverse logistics [19]. The study is theoretically justified because it is based on administrative and engineering theories. Also, the implementation and results will be necessary for the companies under study, as well as for future studies, which is why experimental research was conducted in 8 months, and the results were 
encouraging.

\section{Method}

The research was based on the positivist paradigm, quantitative approach, for which five companies participated, the implementation of the 5s methodology was carried out in three months, where the staff was trained, and daily reinforcements were carried out, as well as corrective measures, in such a way that they acquire a new form of work [20].

The approach was quantitative; the measurement of the variable both in the pre and in the post-test was performed with the support of the numbers. Also, it was statistically inferred, in addition to the hypothesis test [21].

The type was applied, because the $5 \mathrm{~s}$ methodology and the existing KPIs were implemented, to improve a problematic situation, which is the rationale for scientific research.

The design was experimental, specifically pre-experimental, so the five companies were considered as the experimental group, and the data for the first three months: May, June, and July were considered as the pre-test. While the data or KPIs of the October, November, and December, in order to compare the results and demonstrate that the application of the $5 \mathrm{~s}$ improves customer satisfaction rates, as shown in Figure 1 [22] [23].

Consequently, customer service was measured with the following:

1) KPI1 Perfect deliveries refer to the delivery of the products as requested by the customer, EP = (Perfect delivered orders $) /($ Total orders delivered $)$;

2) KPI 2 Deliveries on time, delivery of orders in the promised time, ET = (Orders delivered on time)/(Total orders delivered);

3) KPI 3 Complete deliveries: delivery of orders as requested in quantities, EC $=($ No. orders delivered complete $) /($ Total shipments required $)$;

4) KPI 4 Invoices without problems, an agreement between the requested, delivered and registered, FS = (Invoices without errors)/(Total invoices).

The data were analyzed with the support of descriptive and inferential statistics with the $\mathrm{T}$ student test because the data presented normal distribution according to the Shapiro Wilk test.

\section{Experiment and Results}

After the application of the $5 \mathrm{~s}$ to improve the customer service measured according to the ratios or KPIs indicated above, it is observed that the average for perfect deliveries increased by $36.74 \%$, on-time deliveries by $17.64 \%$, full deliveries

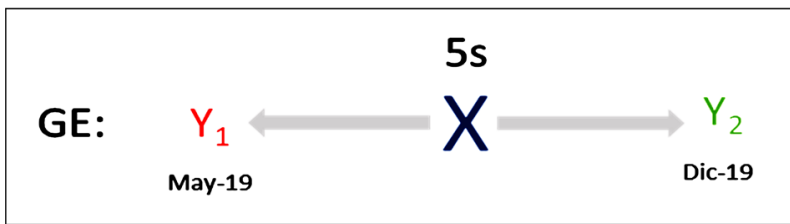

Figure 1. Research design. 
9.31\% and Invoices without problems $30.64 \%$. On the other hand, the standard deviation decreased in all KPIs, which shows that the behaviors of the workers were homogeneous, which is why the results were stable, as shown in Table 1.

Figure 2 compares the results of KPI 1: Perfect deliveries, when comparing Table 1. Descriptive statistics of KPIs in the pre and post-test.

\begin{tabular}{ccccc}
\hline & Test & N & Media & Standard deviation \\
\hline KPI_1 & Pre & 15 & 45.2220 & 3.89316 \\
& Pos & 15 & 81.9620 & 10.55148 \\
KPI_2 & Pre & 15 & 49.4804 & 15.38577 \\
& Pos & 15 & 67.1168 & 14.24391 \\
KPI_3 & Pre & 15 & 24.2599 & 2.11109 \\
& Pos & 15 & 33.5663 & 1.79953 \\
KPI_4 & Pre & 15 & 17.4859 & 2.58725 \\
& Pos & 15 & 48.1225 & 16.78323 \\
\hline
\end{tabular}

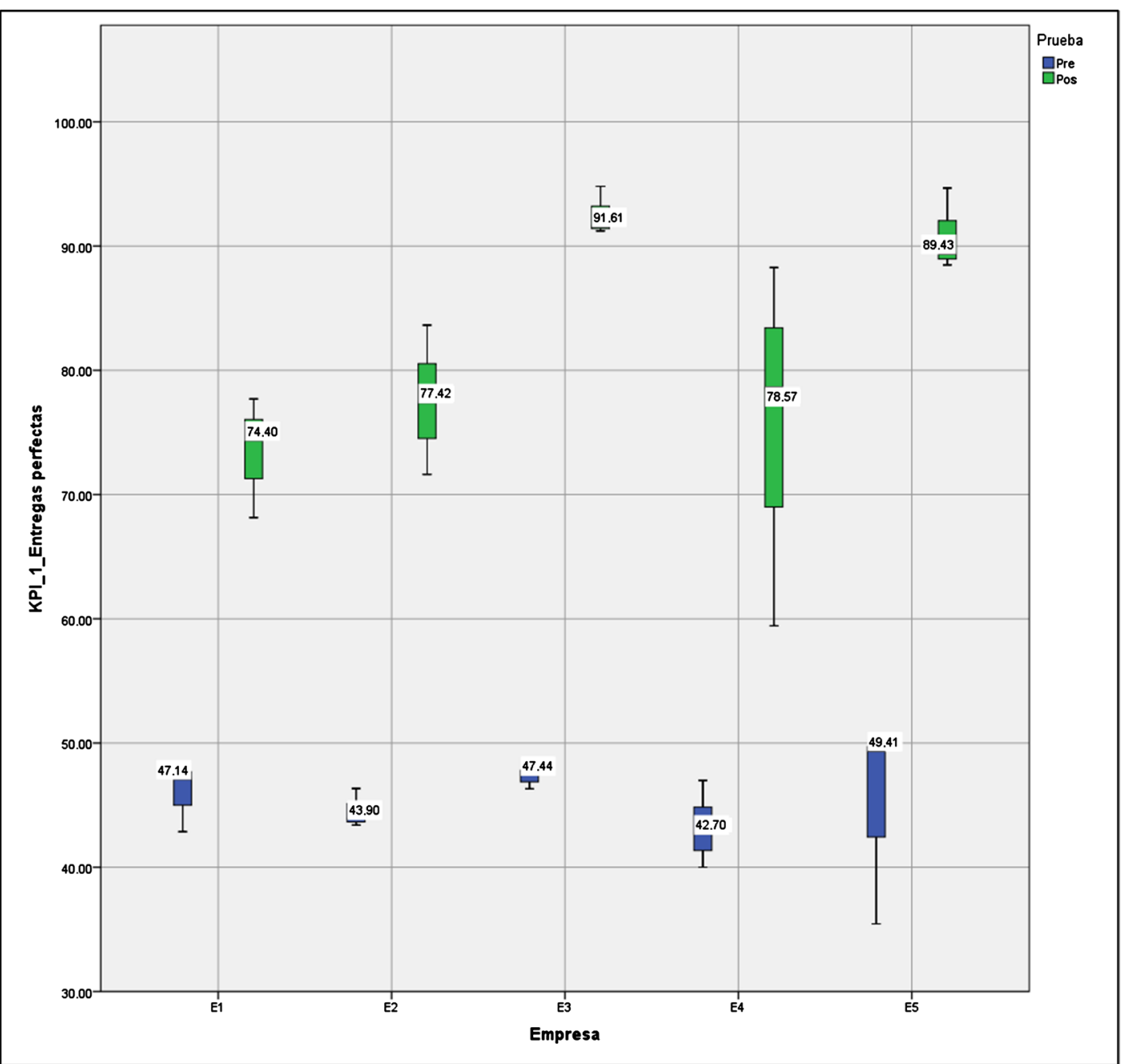

Figure 2. Comparison between the KPIs pre and post-test perfect deliveries. 
the median in the five companies, drastic modification is observed in company 3 and 5 , where the value of $47.77 \%$ to $91.61 \%$ and $49.41 \%$ to $89.46 \%$ respectively were modified., the average was $42 \%$. While in company 4 , there was a modification from $42.70 \%$ to $78.57 \%$, but the data were more dispersed, which meant an increase of $35.87 \%$. In addition, in the case of companies 1 and 2, there were modifications, managing to improve the KPIs from $47.14 \%$ to $74.40 \%$ and from $43.90 \%$ to $77.42 \%$ respectively, which on average, was $30.39 \%$.

Figure 3 compares the results of KPI 1: Deliveries on time, observing that in the case of companies 3, 4 and 5 there were drastic improvements, so that the median increase from $56.41 \%$ to $67.57 \%$, from $42.17 \%$ to $62.50 \%$ and from $20.24 \%$ to $66.67 \%$ respectively, on average the increase was $23.14 \%$. In company 2 , it increased from $58.10 \%$ to $61.29 \%$, which meant an increase of $3.19 \%$. However, in company one, the expected goal was not achieved, because, on the contrary, the result decreased from $69.41 \%$ to $57.78 \%$. When analyzing one of the factors is that there is a lot of staff turnover, basically due to the remoteness of the company, and there is not ease of mobility.

Figure 4 compares the results of KPI complete deliveries, where there are drastic changes in the five companies. The average of the median increased by

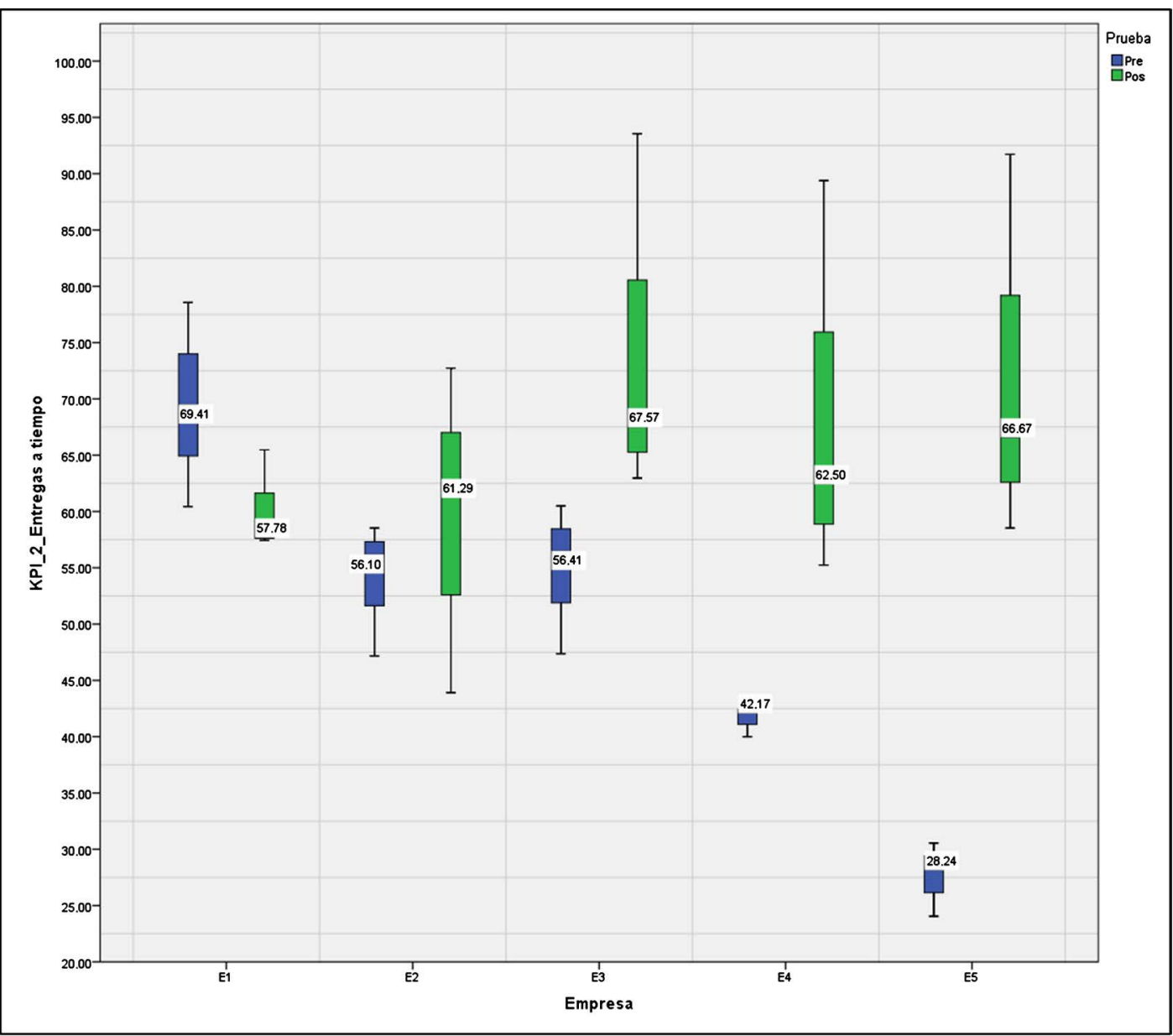

Figure 3. Comparison between the pre and post-test of the KPIs Deliveries on time. 


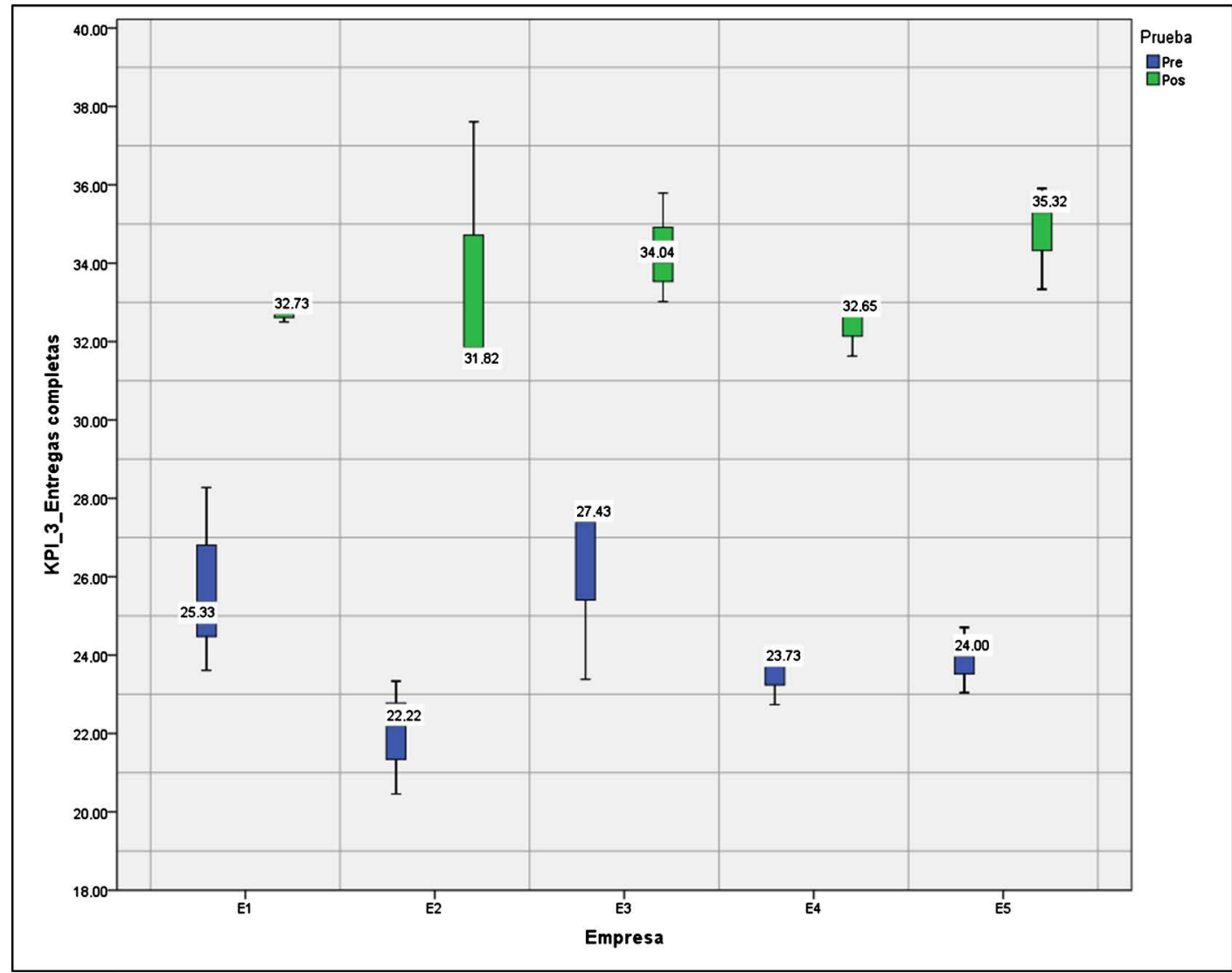

Figure 4. Comparison between the KPIs pre and post-test complete deliveries.

$8.77 \%$, with the best results being company 2,4 , and 5 .

Figure 5 shows the results of the KPI Invoices without problems, where the five companies improved their results. Therefore it shows that SUNAT was taxed according to sales, no cancellations were made, and customers also reduced the tax problem. In the case of the company 1, 2, 3 and 4, the results improved on average concerning the median by $23.92 \%$, while the company 5 increased by $38.14 \%$.

Table 2 shows the results of the Shapiro Wilk test $(n<30)$, where the values of the level of significance exceeded 0.05 , therefore, it is accepted that the data have a normal distribution in the pre and the post-test. This situation led to the application of the parametric $\mathrm{T}$ student test.

The hypotheses raised were:

$\mathrm{H}_{1}$ : The application of the $5 \mathrm{~s}$ will improve perfect deliveries in industrial companies, Lima.

$\mathrm{H}_{0}$ : The application of the $5 \mathrm{~s}$ will not improve perfect deliveries in industrial companies, Lima.

$\mathrm{H}_{2}$ : The application of the $5 \mathrm{~s}$ will improve deliveries on time in industrial companies, Lima.

$\mathrm{H}_{0}$ : The application of the $5 \mathrm{~s}$ will not improve deliveries on time in industrial companies, Lima. 


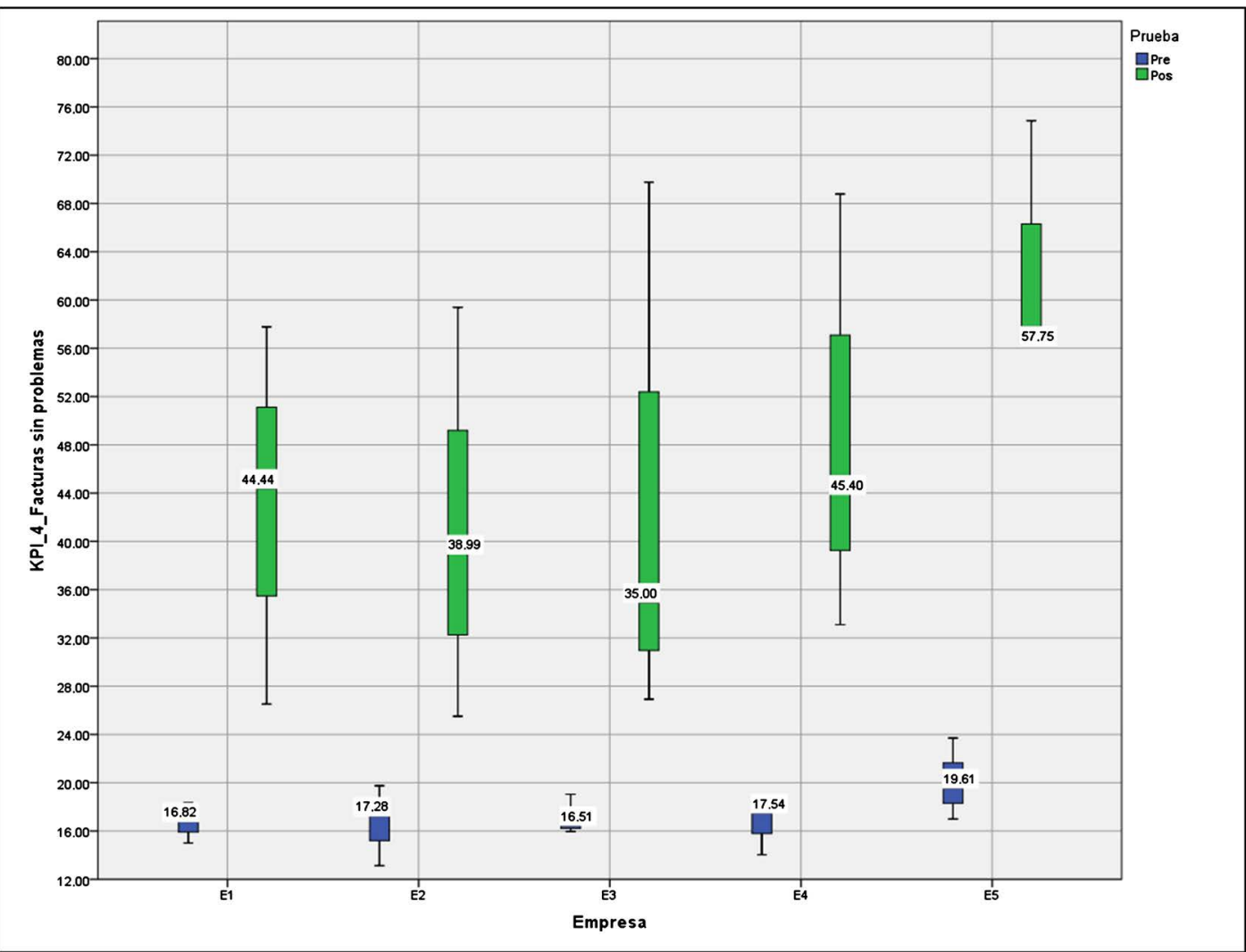

Figure 5. Comparison between the pre and post-test of the KPIs Invoices without problems.

Table 2. Normality test applied to KPIs with the Shapiro Wilk test.

\begin{tabular}{|c|c|c|c|c|}
\hline \multirow{2}{*}{ KPI } & \multirow{2}{*}{ Test } & \multicolumn{3}{|c|}{ Shapiro-Wilk } \\
\hline & & Statistical & gl & Sig. \\
\hline \multirow[t]{2}{*}{ KPI_1 } & Pre & 0.960 & 15 & 0.694 \\
\hline & Pos & 0.946 & 15 & 0.462 \\
\hline \multirow[t]{2}{*}{ KPI_2 } & Pre & 0.971 & 15 & 0.868 \\
\hline & Pos & 0.986 & 15 & 0.994 \\
\hline \multirow[t]{2}{*}{ KPI_3 } & Pre & 0.904 & 15 & 0.108 \\
\hline & Pos & 0.933 & 15 & 0.298 \\
\hline \multirow[t]{2}{*}{ KPI_4 } & Pre & 0.974 & 15 & 0.911 \\
\hline & Pos & 0.888 & 15 & 0.062 \\
\hline \multirow[t]{2}{*}{ KPI_5 } & Pre & 0.932 & 15 & 0.291 \\
\hline & Pos & 0.886 & 15 & 0.058 \\
\hline \multirow[t]{2}{*}{ KPI_6 } & Pre & 0.963 & 15 & 0.745 \\
\hline & Pos & 0.925 & 15 & 0.231 \\
\hline
\end{tabular}

$\mathrm{H}_{3}$ : The application of the $5 \mathrm{~s}$ will improve complete deliveries in industrial companies, Lima.

$\mathrm{H}_{0}$ : The application of the $5 \mathrm{~s}$ will not improve complete deliveries in industrial 
companies, Lima.

$\mathrm{H}_{4}$ : The application of the $5 \mathrm{~s}$ will improve the delivery of invoices without problems in industrial companies, Lima.

$\mathrm{H}_{0}$ : The application of the $5 \mathrm{~s}$ will not improve the delivery of invoices without problems in industrial companies, Lima.

After the data collection and the application of the $\mathrm{T}$ student test, it was shown that they have equal variances. In the case of KPI 1, the T value was -12.652 , gl. 28 and $\mathrm{p}=0.000$; for KPI 2 the $\mathrm{T}$ value was -3.258 , gl. 28 and $\mathrm{p}=$ 0.000; The KPI $3 \mathrm{~T}$ value was -12.993 , gl. 28 and $\mathrm{p}=0.000$; KPI 4 the T value was -6.987 , gl. 28 and $\mathrm{p}=0.000$.

It has been shown that the null hypothesis was rejected, and it was shown that the application: The 5s improved the perfect, timely, complete deliveries and invoices without problems in Lima. The results harmonize with Al Amin, Roy, Rahman, \& Imran (2019), Loayza (2019) and De la Cruz (2018) because it also improved productivity and efficiency, also coincides with Rizkya, Syahputri, Sari, \& Siregar (2019) and Jiménez, Romero, Fernández, Espinosa, \& Domínguez (2019) given that resources improved in order and time was not wasted in their search. It is also harmonized concerning the improvement of human relationships and employee satisfaction with Zubia, Brito, \& Fereiro (2018) and Hernández, Camargo, \& Martínez (2015). Consequently, this work contributes to business management and invites researchers to implement this methodology to improve their productivity and effectiveness indices, which is beneficial for shareholders and collaborators, not only in the company but also in life daily.

\section{Conclusions}

The methodology of the $5 \mathrm{~s}$ helped drastically in improving the company's results regarding the delivery of perfect, timely, complete, and trouble-free orders as demonstrated statistically with the $\mathrm{T}$ student test. The $5 \mathrm{~s}$ methodology implied the change of attitude of the workers; of course at the beginning it was complicated in each of them because the workers were in their comfort zone and preferred to continue working in the same way, although they complained that things were not in place and wasting time. However, as the days progressed, they gradually accepted and became involved, such as cleaning their workspace at the end of the day, if any tool was out of place, on their initiative they returned it to their place, even though they did not use it, they verified the orders before sending them. When they returned the truck, they asked if it was delivered on time. This situation improved not only the numerical results but also the working environment improved, there was more exceptional communication between the staff, and they stated that at home, they were also making their attempts to implement them. The $5 \mathrm{~s}$ methodology is applicable to different companies and areas, it is cheap in its application, but it requires much effort from who directs it, in addition to being empathic, because authoritarianism does not work in this case. 
The research having been carried out under a pre-experimental design in five companies allowing the application of the 5s methodology in eight months; in this sense, there is the existence of different cultures, climate, and staff performance, among others. Unfortunately, its acceptance was not rapid. However, with the proactivity and tenacity of the researchers, it was possible to obtain positive and encouraging results. We also consider that in order for the intervention to be sustained, this methodology should continue to be applied in the companies for three years, so that the workers incorporate said guidelines in your daily work. Therefore, this work turns out to be important because, despite the years, the $5 \mathrm{~s}$ methodology is still in force, it is also cheap, its objective lies in the change of attitude for the achievement of the organizational objectives.

\section{Conflicts of Interest}

The authors declare no conflicts of interest regarding the publication of this paper.

\section{References}

[1] Joerss, M., Schroder, J., Neuhaus, F., Klink, C. and Mann, F. (2016) Parcel Delivery. The Future ef Last Mile. McKinsey \& Company, New York.

[2] Boroski, A. (2019) Shipping \& Logistics. https://www.shiplilly.com/es/blog/la-escasez-de-almacenes-en-los-ee-uu-provocaraun-aumento-de-los-alquileres-en-2019

[3] Dinero (2018) Dinero. https://www.dinero.com/edicion-impresa/informe-especial/articulo/que-debe-mejo rar-en-la-logistica-en-colombia/257201

[4] Al Amin, M., Roy, S., Rahman, A. and Imran, M. (2019) Implementation of 5s in Jute Mill: A Case Study. Journal of Engineering Science, 10, 77-84.

[5] Rizkya, I., Syahputri, K., Sari, R. and Siregar, I. (2019) 5S Implementation in Welding Workshop-A Lean Tool in Waste Minimization. 1 st International Conference on Industrial and Manufacturing Engineering, Medan, 16 October 2018, 1-4. https://doi.org/10.1088/1757-899X/505/1/012018

[6] Jiménez, M., Romero, L., Fernández, J., Espinosa, M. and Domínguez, M. (2019) Extension of the Lean 5S Methodology to 6S with An Additional Layer to Ensure Occupational Safety and Health Levels. Sustainability, 11, 1-18. https://doi.org/10.3390/su11143827

[7] Zubia, S., Brito, J. and Fereiro, V. (2018) Mejora continua: Implementación de las 5s en una microempresa. Revista Global de Negocios, 6, 97-110.

[8] Hernández, E., Camargo, Z. and Martínez, P. (2015) Impact of 5S on Productivity, Quality, Organizational Climate and Industrial Safety in Caucho Metal Ltda. Ingeniare, 23, 107-117. https://doi.org/10.4067/S0718-33052015000100013

[9] Loayza, M. (2019) Implementación de las 5S en la empresa Abralit S.A. de Arequipa durante el periodo del 2018. Tesis de maestría. UNSA, Arequipa.

[10] De la Cruz, A. (2018) Estrategia de mejora continua 5S para la optimización en el despacho de medidores de agua en el almacén de Lima, 2016. Tesis de maestría. UCV, Lima.

[11] Globerson, A. and Wolbrum, G. (2014) Logistics Management and Supply Chain 
Management: A Critical Evaluation. International Journal of Business and Economics Research, 3, 82-88. https://doi.org/10.11648/j.ijber.20140302.15

[12] Chiavenato, I. (2014) Introducción a la teoría general de la administración, México. McGraw-Hill, New York.

[13] Romero, J., Ortiz, V. and Caicedo, Á. (2019) La teoría de restricciones y la optimización como herramientas gerenciales para la programación de la producción. Una aplicación en la industria de muebles. Revista de métodos cuantitativos para la economía y la empresa, 27, 74-90.

[14] Jiménez, J. (2015) Marco conceptual de la cadena de suministro: Un enfoque logístico, Sanfandila: Instituto Mexicano del Transporte.

[15] Agrahari, R., Dangle, K. and Chandratre, K. (2015) Implementation of 5S Methodology in the Small Scale Industry: A Case Study. International Journal of Scientific \& Technology Research, 4, 180-187.

[16] Filip, F. and Marascu-Klein, V. (2015) The 5S Lean Method as a Tool of Industrial Management Performances. Modern Technologies in Industrial Engineering, 95, 1-6. https://doi.org/10.1088/1757-899X/95/1/012127

[17] Falkowski, P. and Kitowski, P. (2018) The 5s Methodology as a Tool for Improving Organization of Production. Interdisciplinary Journal, 4, 127-133.

[18] Correa, A., Gómez, R. and Cano, J. (2010) Gestión de almacenes y tecnologías de la información y comunicación (TIC). Estudios Gerenciales, 26, 145-171. https://doi.org/10.1016/S0123-5923(10)70139-X

[19] Wolters Kluwer (2016) La gestión del almacén en la pyme. Wolters Kluwer, Alphen aan den Rijn.

[20] Ramos, A. (2015) Los paradigmas de la investigación científica. Avances en Psicología, 23, 9-17. https://doi.org/10.33539/avpsicol.2015.v23n1.167

[21] Durán, D. (2019) Instrumentos de investigación cualitativos y cuantitativos frente a la investigación mixta o complementaria. Consensus, 3, 41-56.

[22] Hernández, R., Fernández, C. and Baptista, M. (2014) Metodología de la investigación. McGraw-Hill, New York.

[23] Hernández-Sampieri, R. and Mendoza, C. (2018) Metodología de la investigación. Las rutas cuantitativa, cualitativa y mixta. McGraw Hill, New York. 